\title{
Effect of zinc supplementation on in vitro copper-induced oxidation of low-density lipoproteins in healthy French subjects aged 55-70 years: the Zenith Study
}

\author{
Christine Feillet-Coudray ${ }^{1 *}$, Nathalie Meunier ${ }^{1}$, Dominique Bayle $^{1}$, Marion Brandolini-Bunlon ${ }^{2}$, \\ Maud Andriollo-Sanchez ${ }^{3}$, Jacqueline M. O’Connor ${ }^{4}$, Giuseppe Maiani ${ }^{5}$, Anne-Marie Roussel ${ }^{3}$, \\ Andrzej Mazur ${ }^{1}$ and Charles Coudray ${ }^{1}$ \\ ${ }^{1}$ Centre de Recherche en Nutrition Humaine d'Auvergne, Unité Maladies Métaboliques et Micronutriments, \\ INRA Clermont/Theix, France \\ ${ }^{2}$ Laboratoire de Nutrition Humaine, 58 Rue Montalembert, 63000 Clermont-Ferrand, France \\ ${ }^{3}$ Laboratoire de Nutrition, Vieillissement et Maladies Cardiovasculaires, Faculté de Pharmacie Domaine de la Merci, \\ 38700 La Tronche, France \\ ${ }^{4}$ Northern Ireland Centre for Food and Health (NICHE), University of Ulster, Coleraine BT52 1SA, UK \\ ${ }^{5}$ National Institute for Food and Nutrition Research, Human Nutrition Unit, Via Ardeatina 546, 00178 Roma, Italy
}

(Received 28 October 2005 - Revised 23 January 2006 - Accepted 25 January 2006)

\begin{abstract}
$\mathrm{Zn}$ has been shown to possess antioxidant properties in vitro and in vivo. As inadequate dietary $\mathrm{Zn}$ intake has been reported in these populations, $\mathrm{Zn}$ supplementation may protect against oxidative stress and thereby limit the progression of degenerative diseases in such populations. We conducted the present study to evaluate the long-term supplementation effects of two moderate doses of $\mathrm{Zn}$ on in vitro $\mathrm{Cu}$-induced LDL oxidation in French men and women. Three groups of sixteen healthy subjects aged 55-70 years from each sex participated in this randomized double-blind, placebocontrolled study. Each group received for six months either 0,15 or $30 \mathrm{mg}$ supplemental $\mathrm{Zn}$ per d. At the beginning and at the end of the supplementation periods, dietary intakes of $\mathrm{Zn}, \mathrm{Cu}, \mathrm{Fe}$ and vitamin $\mathrm{E}$ were estimated using $4 \mathrm{~d}$ food-intake records (including the weekend) and the GENI program. $\mathrm{Zn}, \mathrm{Cu}, \mathrm{Fe}$ and vitamin $\mathrm{E}$ status were also determined. In vitro LDL oxidizability (basal conjugated diene level, maximal conjugated diene formation and lag time) and lipid parameters were also determined. Dietary intakes of $\mathrm{Zn}, \mathrm{Cu}, \mathrm{Fe}$ and vitamin $\mathrm{E}$ were adequate in this population. Zn supplementation significantly increased serum $\mathrm{Zn}$ levels but did not significantly modify $\mathrm{Cu}$, $\mathrm{Fe}$ or vitamin $\mathrm{E}$ status. However, $\mathrm{Zn}$ supplementation had no effect on in vitro LDL oxidation parameters, nor were there any sex-related differences in in vitro LDL oxidizability. The present study showed that long-term $\mathrm{Zn}$ supplementation of healthy subjects aged 55-70 years had no effect on in vitro Cu-induced LDL oxidation under the study conditions.
\end{abstract}

Low-density lipoprotein: Oxidation: Zinc status: Zinc supplementation: Human subjects

The involvement of free radical oxygen species in the general ageing process has been well documented, and an enhanced oxidative stress in elderly people has been reported to increase the incidence of pathologies such as CVD, cancer and diabetes (Harman, 1992). Uncontrolled free radical production in ageing is considered to result from both an enhanced production of reactive oxygen species, especially through the mitochondrial pathway (Balaban et al. 2005), and through lowered antioxidant defences. Several studies have demonstrated that endogenous antioxidant defences and antioxidant enzyme activities decline with age (Napoli et al. 1997; Jones et al. 2002; Maggio et al. 2003) while nutritional antioxidant intakes decrease (Vaquero, 2002). Low intakes of antioxidant nutrients such as vitamins and trace elements such as $\mathrm{Zn}$ might, therefore, play an important role in atherogenesis (Reaven et al. 1999).

The antioxidant properties of $\mathrm{Zn}$ have been demonstrated both in vitro and in vivo and several mechanisms have been advanced. These mechanisms include, in particular, the protection of protein sulphydryl groups against oxidation and the direct inhibition of the production of reactive oxygen species by transition metals (Bray \& Bettger, 1990; Powell, 2000). Another possible antioxidant action of $\mathrm{Zn}$ could be related to protection against vitamin $\mathrm{E}$ restriction, the contribution to the structure of the antioxidant enzyme $\mathrm{Zn}, \mathrm{Cu}$-superoxide dismutase, and the maintenance of tissue concentrations of metallothionein, a powerful free radical scavenger (DiSilvestro, 2000). Zn was also shown to decrease in vitro

\footnotetext{
Abbreviation: TBARS, thiobarbituric acid reactive substances.

* Corresponding author: Dr Christine Feillet-Coudray, fax +334736246 38, email cfeillet@ensam.inra.fr
} 
Fe-dependent hydroxy radical production (Coudray et al. 1993). Such functions might act to prevent or attenuate the oxidation of biological molecules, in particular the lipid components. Therefore, $\mathrm{Zn}$ supplementation may be beneficial against oxidative stress and may directly or indirectly modify in vivo LDL oxidizability, thereby counteracting the atherosclerotic process (Gatto \& Samman, 1995; Hennig et al. 1996; Beattie \& Kwun, 2004). Zn is also known to modify lipid metabolism (Hiller et al. 1995; Schlegel-Zawadzka et al. 2004), and thus, by changing the LDL fatty acid composition, Zn could indirectly modify in vivo LDL oxidizability. Although some studies have already demonstrated that $\mathrm{Zn}$ supplementation may improve endothelial cell functions (McClain et al. 1995) and play a role in the prevention of CVD (Hercberg et al. 1998), there are still very few studies that have investigated the effect of $\mathrm{Zn}$ supplementation on LDL oxidation in man (Gatto \& Samman, 1995).

The present study aimed to investigate, in French subjects aged 55-70 years, the potential beneficial effect on the time-course of in vitro LDL oxidation of long-term $\mathrm{Zn}$ supplementation using two moderate doses of $\mathrm{Zn}$, corresponding to about one-and-a-half and three times the French RDA for $\mathrm{Zn}$ which are set at $9.5 \mathrm{mg} / \mathrm{d}$ for women and at $11.5 \mathrm{mg} / \mathrm{d}$ for men (Arnaud, 2001). Moreover, because of the close link between $\mathrm{Zn}$ and other nutritional antioxidant or pro-oxidant micronutrients such as $\mathrm{Cu}, \mathrm{Fe}$ and vitamin $\mathrm{E}$, and their possible impact on in vivo LDL oxidizability, the dietary intake and the status of these micronutrients were also determined in the present study.

\section{Subjects and methods}

\section{Study design}

The study design was a randomized, double-blind, placebocontrolled intervention trial in men and women aged 55-70 years. Subjects were randomly assigned to one of three groups to receive either a placebo, or 15 or $30 \mathrm{mg} \mathrm{Zn} / \mathrm{d}$ as two capsules in the morning for 6 months. The supplemental $\mathrm{Zn}$ was given as Zn gluconate, which was prepared and supplied by E-Pharma (Creapharm, Gannat, France). The placebo capsule contained $199 \mathrm{mg}$ lactose and $1 \mathrm{mg}$ magnesium stearate. The $7.5 \mathrm{mg} \mathrm{Zn}$ capsule contained $56.9 \mathrm{mg} \mathrm{Zn}$ gluconate, $142.1 \mathrm{mg}$ lactose and $1 \mathrm{mg}$ magnesium stearate. The $15 \mathrm{mg}$ $\mathrm{Zn}$ capsule contained $113.7 \mathrm{mg} \mathrm{Zn}$ gluconate, $85.3 \mathrm{mg}$ lactose and $1 \mathrm{mg}$ magnesium stearate. The capsules of the three batches were identical in their shape, colour and weight. Capsules were distributed to the subjects at the beginning of the trial and at 3 months. At 3 and 6 months, subjects were asked to return any remaining capsules, and the degree of apparent compliance was estimated from the number of delivered capsules and the number of returned capsules. Blood and urine samples were taken prior to supplementation and after 6 months of $\mathrm{Zn}$ supplementation. Blood samples were collected at 08.00 hours after an overnight fast, by venepuncture into EDTA, in heparinized, trace element-free heparinized and non-anticoagulant-containing tubes for $\mathrm{Zn}, \mathrm{Cu}, \mathrm{Fe}$ and vitamin $\mathrm{E}$ status assessment, in vitro $\mathrm{Cu}$-induced $\mathrm{LDL}$ oxidizability and serum lipid profile determination.

\section{Subjects}

A total of ninety-six healthy subjects (forty-eight females and forty-eight males, aged 55-70 years) participated in the present study. Clinical examination was carried out by the medical staff at the Unit of Nutritional Exploration (UEN) of the Human Nutrition Research Center (CRNH) of the Auvergne, in France. All subjects were non-smokers and were judged to be healthy on the basis of a physical examination, medical history and a routine blood screening. At the time of recruitment and throughout the duration of the study, none of the enrolled subjects took vitamin or mineral supplements or medications which may have affected mineral metabolism. Dietary intakes of $\mathrm{Zn}, \mathrm{Cu}, \mathrm{Fe}$ and vitamin $\mathrm{E}$ were estimated using $4 \mathrm{~d}$ food-intake records. Participants were asked to maintain their habitual diet and exercise patterns for the duration of the study. The study was approved by the local human ethical committee (Comité Consultatif de Protection des Personnes en Recherche Biomedicale Auvergne, Clermont-Ferrand, France) under number AU 478. All participants were fully informed of the objectives of the study and gave their written consent. Three groups of thirty-two people (sixteen females and sixteen males in each group) were randomly assigned to the experimental design; group 1 received a placebo, group 2 received $15 \mathrm{mg} \mathrm{Zn/d}$ and group 3 received $30 \mathrm{mg} \mathrm{Zn/d}$.

\section{Dietary intake of micronutrients: $\mathrm{Zn}, \mathrm{Cu}, \mathrm{Fe}$ and vitamin $\mathrm{E}$}

At the beginning and at the end of each supplementation period, dietary intakes of micronutrients were estimated using $4 \mathrm{~d}$ food-intake records (including weekend). Each volunteer had received a notebook with one table per meal or snack to fill in. They had to note for each meal or snack, the names of foods and drinks, and the quantities ingested by an estimation using domestic measurements. The dietary data were checked with a dietitian, using a picture book for the estimations of quantities which has been validated (Le Moullec et al. 1996). Using the correspondence between the reference of the picture and the weight of food given in a table, all the dietary data were converted into grames of food or drink ingested. Then, nutrient intakes were estimated using the dietetics software 'GENI' (Gestion des Enquêtes Nutritionnelles Informatisée; Micro 6, Villers-lès-Nancy, France), whose food composition table is derived from the Répertoire général des aliments (Favier et al. 1995).

\section{Status biomarkers of micronutrients: $\mathrm{Zn}, \mathrm{Cu}, \mathrm{Fe}$ and vitamin $\mathrm{E}$}

The trace element-free heparinized or non-anticoagulant-containing blood tubes were centrifuged $\left(1000 \mathrm{~g}, 10 \mathrm{~min}, 4^{\circ} \mathrm{C}\right)$ and serum, plasma and erythrocytes were collected and stored at $-20^{\circ} \mathrm{C}$ until analysis. First morning urine samples were collected after a $12 \mathrm{~h}$ fasting period. Samples were then acidified with pure $\mathrm{HCl}$ (final acid concentration: 1\%) and stored at $-20^{\circ} \mathrm{C}$ until analysis. For $\mathrm{Zn}$ analysis, serum and urine were diluted in $0 \cdot 1 \mathrm{M}-\mathrm{HCl}(1: 5, \mathrm{v} / \mathrm{v})$ and erythrocytes were diluted in de-ionized water $(1: 100, \mathrm{v} / \mathrm{v})$ and $\mathrm{Zn}$ concentration was determined on a flame atomic absorption spectrophotometer (560; Perkin-Elmer, Paris, France) at $214 \mathrm{~nm}$ (Arnaud et al. 1986). Urinary creatinine concentrations were measured by colorimetry (Hill et al. 2005) and the ratio of $\mathrm{Zn}$ to creatinine was 
calculated. Serum Fe, ferritin and transferrin saturation and serum $\mathrm{Cu}$ levels and erythrocyte superoxide dismutase activity were measured as previously described (Andriollo-Sanchez et al. 2005). Plasma vitamin E level was determined by HPLC as previously described by Maiani et al. (1989).

\section{Serum lipid profile}

Serum samples were obtained from blood drawn in anticoagulant tubes for lipid, determination following centrifugation $\left(1000 \mathrm{~g}, 10 \mathrm{~min}, 4^{\circ} \mathrm{C}\right)$, and stored at $-80^{\circ} \mathrm{C}$ until analysis. Serum triacylglycerols, total cholesterol, LDL-cholesterol and HDL-cholesterol were determined by photometric analysis on a Hitachi 912 Clinical Chemistry Autoanalyzer, using commercially available kits purchased from Roche Diagnostics Ltd (Welwyn Garden City, UK).

\section{$L D L$ isolation and in vitro oxidation}

LDL was isolated as follows (Rayssiguier et al. 1993): EDTA blood samples were centrifuged $\left(1000 \mathrm{~g}, 10 \mathrm{~min}, 4^{\circ} \mathrm{C}\right)$ within $1 \mathrm{~h}$ of collection. Plasma was collected and mixed with a sucrose solution to a final concentration of $6 \mathrm{~g} / \mathrm{l}(0.6 \%)$, then stored at $-80^{\circ} \mathrm{C}$ until analysis. Plasma was adjusted to a density of $1.019 \mathrm{~g} / \mathrm{ml}$ with potassium bromide to extract VLDL and then to $1.063 \mathrm{~g} / \mathrm{ml}$ to collect LDL. Ultra-centrifugation was performed twice at $15^{\circ} \mathrm{C}$, at $645000 \mathrm{~g}$, for $2 \mathrm{~h}$, in a Beckman Optima L-90 model ultracentrifuge (Beckman Instrument, Palo Alto, CA, USA) with a Beckman NVT 90 rotor. The yellow LDL fraction was removed and dialysed at $4^{\circ} \mathrm{C}$ in darkness for $24 \mathrm{~h}$ against $0.01 \mathrm{M}-\mathrm{PBS}$ ( $\mathrm{pH} 7 \cdot 4$ ) containing $0.15 \mathrm{M}-\mathrm{NaCl}$, which was made oxygen-free by vacuum degassing followed by purging with nitrogen.

In vitro oxidation experiments were performed on freshly prepared LDL as previously described (Feillet et al. 1998). Briefly, LDL was diluted with PBS to a final concentration of $50 \mu \mathrm{g}$ protein $/ \mathrm{ml}$ and oxidation was initiated by adding freshly prepared $\mathrm{CuCl}_{2}$ (final concentration $5 \mu \mathrm{mol} / \mathrm{l}$ ). Absorbance at $234 \mathrm{~nm}$ was continuously monitored for $8 \mathrm{~h}$ in the spectrophotometer (Uvikon 820; Kontron, St-Quentin-en-Yvelines, France) and oxidation was determined as the production of conjugated diene. Lag time, which represents resistance to oxidation, was determined as the intercept of the baseline and propagation phase of the absorbance curve.

\section{Statistical analyses}

Results are expressed as means and standard deviations. Statistical analyses were based on a two-way or a three-way repeated measure ANOVA with interactions on simple linear regression and on Spearman's correlation coefficients. The limit of statistical significance was set at $P<0 \cdot 05$. Statistical analyses were performed using Statview software (SAS Institute Inc., Cary, NC, USA).

\section{Results}

\section{Subject characteristics}

As shown in Table 1, no significant differences were observed between the three groups according to sex and in terms of age, height, body weight and BMI. Of the ninety-six recruited subjects, ninety-five subjects completed the 6-month $\mathrm{Zn}$ supplementation study. Only one subject dropped out before the end of the trial (a woman in group 3). Analysis of the returned capsules revealed that compliance was greater than $98 \%$.

\section{Dietary intakes of micronutrients: zinc, copper, iron and vitamin $E$}

As shown in Table 2, daily dietary intake of $\mathrm{Zn}$ (about $13 \mathrm{mg}$ in men and $10 \mathrm{mg}$ in women), $\mathrm{Cu}$ (about $1.3 \mathrm{mg}$ in men and $1.1 \mathrm{mg}$ in women), $\mathrm{Fe}$ (about $14 \mathrm{mg}$ in men and $10 \mathrm{mg}$ in women) and vitamin $\mathrm{E}$ (about $11 \mathrm{mg}$ in men and $9 \mathrm{mg}$ in women), may be considered as adequate in this population compared to the French RDA for this age range. As already reported (Galan et al. 2005), the dietary intake of these micronutrients was significantly higher in men than in women. As expected, there were no significant differences in the dietary intake of these micronutrients with regards to the $\mathrm{Zn}$ administered doses or the period of treatment.

Status biomarkers of micronutrients: zinc, copper, iron and vitamin $E$

Serum $\mathrm{Zn}$ levels were similar in the three groups in both sexes before the $\mathrm{Zn}$ supplementation. As expected, serum $\mathrm{Zn}$ levels increased significantly $(P<0 \cdot 001)$ following $\mathrm{Zn}$ supplementation (Table 3). Erythrocyte $\mathrm{Zn}$ level was significantly higher $(P<0.03)$ in men than in women, and it remained unchanged after $\mathrm{Zn}$ supplementation. Urinary $\mathrm{Zn}$ excretion

Table 1. Characteristics of study population at the beginning of the study (T0)* (Mean values and standard deviations)

\begin{tabular}{|c|c|c|c|c|c|c|c|c|c|c|c|c|c|c|c|}
\hline \multirow[b]{3}{*}{ Parameter } & \multicolumn{4}{|c|}{ Placebo (group 1) } & \multicolumn{4}{|c|}{15 mg Zn/d (group 2) } & \multicolumn{4}{|c|}{30 mg Zn/d (group 3) } & \multicolumn{3}{|c|}{$P$ valuet } \\
\hline & \multicolumn{2}{|c|}{ Men } & \multicolumn{2}{|c|}{ Women } & \multicolumn{2}{|c|}{ Men } & \multicolumn{2}{|c|}{ Women } & \multicolumn{2}{|c|}{ Men } & \multicolumn{2}{|c|}{ Women } & \multirow{2}{*}{$\begin{array}{l}\text { Effect } \\
\text { of sex }\end{array}$} & \multirow{2}{*}{$\begin{array}{l}\text { Effect of } \\
\text { doses }\end{array}$} & \multirow{2}{*}{$\begin{array}{c}\text { Interaction } \\
(\text { sex } \times \text { group })\end{array}$} \\
\hline & Mean & SD & Mean & SD & Mean & SD & Mean & SD & Mean & SD & Mean & SD & & & \\
\hline Age (years) & 62.9 & $3 \cdot 4$ & 61.4 & $4 \cdot 6$ & 59.9 & $4 \cdot 0$ & $61 \cdot 3$ & 4.5 & $61 \cdot 3$ & $4 \cdot 6$ & 60.9 & 4.4 & NS & NS & NS \\
\hline $\begin{array}{l}\text { Body } \\
\quad \text { weight }(\mathrm{kg})\end{array}$ & $77 \cdot 8$ & $8 \cdot 5$ & $65 \cdot 5$ & $8 \cdot 2$ & $77 \cdot 2$ & $8 \cdot 8$ & $65 \cdot 6$ & $8 \cdot 1$ & $75 \cdot 7$ & $9 \cdot 3$ & $67 \cdot 0$ & $6 \cdot 7$ & $<0.0001$ & NS & NS \\
\hline BMI $\left(\mathrm{kg} / \mathrm{m}^{2}\right)$ & $26 \cdot 4$ & $2 \cdot 3$ & 25.9 & $2 \cdot 8$ & 25.9 & 2.7 & 25.5 & $2 \cdot 3$ & $26 \cdot 1$ & $2 \cdot 2$ & $26 \cdot 4$ & $2 \cdot 1$ & NS & NS & NS \\
\hline
\end{tabular}

* $n 16$ men and 16 women (except group 3, where $n 16$ men and 15 women).

†A two-way repeated measure ANOVA with interactions was performed for these parameters. Statistical significance was set at $P<0.05$. 
Table 2. Dietary intakes of zinc, copper, iron and vitamin $\mathrm{E}$ at the beginning of the study (T0) and after 6-month zinc supplementation (T6) ${ }^{\star}$ (Mean values and standard deviations)

\begin{tabular}{|c|c|c|c|c|c|c|c|c|c|c|c|c|c|c|c|c|}
\hline \multirow{2}{*}{ Parameter } & \multicolumn{4}{|c|}{ Placebo (group 1) } & \multicolumn{4}{|c|}{15 mg Zn/d (group 2) } & \multicolumn{4}{|c|}{$30 \mathrm{mg} \mathrm{Zn/d} \mathrm{(group} \mathrm{3)}$} & \multicolumn{4}{|c|}{$P$ value } \\
\hline & \multicolumn{2}{|c|}{ TO } & \multicolumn{2}{|c|}{ T6 } & \multicolumn{2}{|c|}{ TO } & \multicolumn{2}{|c|}{ T6 } & \multicolumn{2}{|c|}{ T0 } & \multicolumn{2}{|c|}{ T6 } & $\begin{array}{l}\text { Effect } \\
\text { of sex }\end{array}$ & $\begin{array}{l}\text { Effect } \\
\text { of } \\
\text { doses }\end{array}$ & $\begin{array}{l}\text { Effect } \\
\text { of } \\
\text { period }\end{array}$ & $\begin{array}{l}\text { Interaction } \\
\text { (sex } \times \text { group } \\
\times \text { period })\end{array}$ \\
\hline $\begin{array}{r}\text { Zn intake } \\
(\mathrm{mg} / \mathrm{d})\end{array}$ & & & & & & & & & & & & & $<0.0001$ & NS & NS & NS \\
\hline Men & $13 \cdot 2$ & 2.5 & $13 \cdot 3$ & 2.5 & $12 \cdot 4$ & $3 \cdot 4$ & $15 \cdot 0$ & 4.6 & $13 \cdot 2$ & 3.5 & $11 \cdot 7$ & $2 \cdot 8$ & & & & \\
\hline $\begin{array}{r}\text { Cu intake } \\
(\mathrm{mg} / \mathrm{d})\end{array}$ & & & & & & & & & & & & & 0.019 & NS & NS & NS \\
\hline Men & $1 \cdot 19$ & 0.32 & 1.35 & 0.38 & $1 \cdot 11$ & 0.46 & 1.46 & 0.55 & $1 \cdot 22$ & 0.48 & 1.35 & 0.60 & & & & \\
\hline Women & $1 \cdot 10$ & 0.24 & 1.22 & 0.84 & 1.09 & 0.54 & 1.08 & 0.37 & $1 \cdot 14$ & 0.63 & 1.01 & 0.34 & & & & \\
\hline $\begin{array}{r}\text { Fe intake } \\
(\mathrm{mg} / \mathrm{d})\end{array}$ & & & & & & & & & & & & & $<0.0001$ & NS & NS & NS \\
\hline Men & $12 \cdot 9$ & 3.0 & $13 \cdot 4$ & 2.9 & $14 \cdot 8$ & $3 \cdot 1$ & $15 \cdot 5$ & $4 \cdot 0$ & $13 \cdot 6$ & $4 \cdot 0$ & $15 \cdot 7$ & $6 \cdot 7$ & & & & \\
\hline Women & $9 \cdot 8$ & $2 \cdot 2$ & $10 \cdot 4$ & $3 \cdot 6$ & $11 \cdot 1$ & $4 \cdot 3$ & 9.6 & $2 \cdot 4$ & $10 \cdot 8$ & $2 \cdot 2$ & $9 \cdot 1$ & $2 \cdot 0$ & & & & \\
\hline Men & $10 \cdot 5$ & 3.9 & $9 \cdot 3$ & 3.5 & $12 \cdot 1$ & 6.9 & 11.0 & $5 \cdot 7$ & $11 \cdot 3$ & $7 \cdot 8$ & $10 \cdot 0$ & $4 \cdot 1$ & & & & \\
\hline Women & $10 \cdot 0$ & 4.5 & $9 \cdot 2$ & 3.6 & $10 \cdot 2$ & $5 \cdot 3$ & $9 \cdot 3$ & 4.4 & $8 \cdot 1$ & 3.8 & 7.9 & $3 \cdot 1$ & & & & \\
\hline
\end{tabular}

${ }^{*} n 16$ men and 16 women (except group 3, where $n 16$ men and 15 women). For details of procedures, see p. 1135

†A three-way repeated measure ANOVA with interactions was performed for these parameters. Statistical significance was set at $P<0.05$.

adjusted to urinary creatinine excretion also increased significantly $(P<0.01)$ over the 6 months of supplementation in the groups receiving 15 and $30 \mathrm{mg} / \mathrm{d}$, with no significant change in the placebo group compared to their baseline values (Table 3 ).

Serum Fe level ranged from 16 to $22 \mu \mathrm{mol} / \mathrm{l}$ and serum transferrin saturation ranged from 32 to $43 \%$. There were no significant effects of sex or treatment on these two Fe biomarkers (Table 4). However, serum ferritin level, that ranged from 98 to $240 \mu \mathrm{g} / \mathrm{l}$, was not affected by $\mathrm{Zn}$ supplementation, but was significantly higher $(P<0 \cdot 0001)$ in men than in women. Serum $\mathrm{Cu}$ level was significantly higher $(P<0.0005)$ in women than in men whereas erythrocyte $\mathrm{Zn}, \mathrm{Cu}$-superoxide dismutase activity was significantly higher $(P<0.02)$ in men than in women. These two $\mathrm{Cu}$ status parameters remained unchanged after $\mathrm{Zn}$ supplementation. Finally, plasma vitamin E level and vitamin E:cholesterol were similar among the three groups at baseline and after 6 months of $\mathrm{Zn}$ supplementation. Moreover, there was no sex effect nor $\mathrm{Zn}$ dose effect on these two parameters.

\section{Serum lipid profile and in vitro LDL oxidation}

Serum lipid profile was similar among the three groups at baseline and after 6 months of Zn supplementation. When both sexes were compared, serum total cholesterol and HDL-cholesterol concentrations were higher in women than in men (Table 5).

Regarding the susceptibility of LDL to in vitro oxidation, there were no significant differences between the three groups at the beginning of the study (Table 6). After 6 months of $\mathrm{Zn}$ supplementation, there was no change in $\mathrm{Cu}$-induced $\mathrm{LDL}$ oxidation compared to the baseline values, and no sex effect was observed. Moreover, no significant correlations were found $(P>0.05)$ between serum $\mathrm{Zn}$ levels $(r=-0.062,-0.025,-0.028)$, plasma vitamin $\mathrm{E}$ levels $(r=-0 \cdot 085,-0 \cdot 022,+0 \cdot 121)$ or plasma vitamin E: cholesterol $(r=-0.021,-0.009,+0.126)$ and the susceptibility of LDL to in vitro oxidation, for basal conjugated diene, maximal conjugated diene and lag time, respectively.

\section{Discussion}

Among essential trace elements, $\mathrm{Zn}$ has been shown to possess antioxidant properties, acting to protect sulphydryl groups against oxidation and participating in the inhibition of free radical production in the Haber-Weiss cycle by competing with transition metals (Bray \& Bettger, 1990; Coudray et al. 1993; Powell, 2000). Thus, it can be postulated that an optimal $\mathrm{Zn}$ status would be a protective factor against deleterious oxidative effects such as lipid peroxidation and LDL oxidation. Low dietary $\mathrm{Zn}$ intakes have been reported in late middleaged and elderly subjects (Briefel et al. 2000) but little is known about the antioxidant effects of $\mathrm{Zn}$ supplementation in these populations. Given that some studies have observed enhanced susceptibility of lipoproteins to oxidation in elderly people compared to young subjects (Khalil et al. 1996; Napoli et al. 1997), we hypothesized that an improvement of $\mathrm{Zn}$ status would lead to a decreased susceptibility of LDL to oxidation. Therefore, we investigated the effect of long-term moderate $\mathrm{Zn}$ supplementation on the in vitro oxidation of LDL in women and men. Our results clearly showed that a

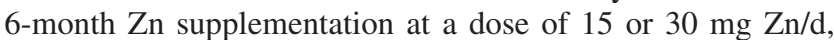
as gluconate, did not affect the $\mathrm{CuCl}_{2}$-induced in vitro $\mathrm{LDL}$ oxidation. There was also no significant sex difference in LDL oxidizability measures.

The antioxidant and the pro-oxidant properties of $\mathrm{Zn}, \mathrm{Fe}$, $\mathrm{Cu}$ and vitamin $\mathrm{E}$ may influence the behaviour and the in vivo LDL composition and thus possibly the in vitro LDL 
oxidation. So, the evaluation of the dietary intake and the status of these micronutrients in studied subjects appear necessary. The daily dietary intake of these micronutrients was adequate in this population as compared to the current French RDA $(9.5 \mathrm{mg} / \mathrm{d}$ for women and 11.5 for men for $\mathrm{Zn}$, $9 \mathrm{mg} / \mathrm{d}$ for women and men for Fe, $1.5 \mathrm{mg} / \mathrm{d}$ for women and men for $\mathrm{Cu}$ and $12 \mathrm{mg} / \mathrm{d}$ for women and men for vitamin E) for this age range (Arnaud, 2001; Azaïs-Braesco et al. 2001; Coudray, 2001; Coudray \& Hercberg, 2001). Moreover, the status biomarkers of these three micronutrients were also adequate compared to the values reported in the literature. These status biomarkers were not affected by $\mathrm{Zn}$ supplementation. However, serum $\mathrm{Zn}$ levels were significantly increased in women and men at both doses, indicating that this lack of effect on LDL oxidation was not owing to poor compliance. Other studies have also demonstrated no effect of $\mathrm{Zn}$ supplementation on LDL susceptibility to oxidation in both diabetic patients (Blostein-Fujii et al. 1997) and healthy subjects (Gatto \& Samman, 1995). Conversely, it has been observed that $\mathrm{Zn}$ supplementation led to decreased thiobarbituric acid reactive substance (TBARS) levels in diabetic patients (Anderson et al. 2001; Roussel et al. 2003) and lowered some markers of oxidative stress, such as malondialdehyde, hydroxynonenal and 8-oxo-D-guanidine, in healthy subjects. Some nutritional antioxidant supplementation studies such as carotenoid supplementation (Hininger et al. 2001) or $\mathrm{Cu}$ supplementation (Turley et al. 2000) in healthy adult subjects failed to observed any significant modification in in vitro LDL oxidation measures, although improvement in particular stress oxidant status parameters was observed. However, in the present study, Zn supplementation did not lead to a significant decrease in plasma TBARS levels or in TBARS: cholesterol ratio (M Andriollo-Sanchez, I Hininger-Favier, N Meunier, JM O'Connor, G Maiani, C Coudray and AM Roussel, unpublished results). Many hypotheses may be put forward to explain the lack of a protective effect of $\mathrm{Zn}$ supplementation on LDL oxidation in the present study. Firstly, the increase in serum $\mathrm{Zn}$ following $\mathrm{Zn}$ supplementation was not strong enough to induce a decrease in LDL oxidation. In our subjects, serum $\mathrm{Zn}$ increased by $18 \%$ at $15 \mathrm{mg} \mathrm{Zn/d}$ and by $24 \%$ at $30 \mathrm{mg} \mathrm{Zn/d}$ after 6 months of Zn supplementation. In another study, Gatto \& Samman (1995) gave $50 \mathrm{mg} \mathrm{Zn}$ as sulphate for 4 weeks and obtained an $18 \%$ increase in serum $\mathrm{Zn}$. They also failed to observe changes in the oxidizability of LDL in their ten young male volunteers (aged about 24 years). Thus, the antioxidant effect of $\mathrm{Zn}$ in relation to LDL oxidizability was not demonstrated in man at $50 \mathrm{mg} \mathrm{Zn/d}$, and higher doses of $\mathrm{Zn}$ are unlikely to be used, given the possible adverse interactions with $\mathrm{Cu}$ and $\mathrm{Fe}$ metabolism. It is also important to note that the studied subjects presented with normal serum $\mathrm{Zn}$ values $(>10.7 \mu \mathrm{mol} / \mathrm{l}$; Gibson, 1990) before $\mathrm{Zn}$ supplementation; therefore, $\mathrm{Zn}$ supplementation does not appear to be beneficial in terms of further improving antioxidant status of these populations as shown by the non-significant modification of plasma TBARS level (M Andriollo-Sanchez, I Hininger-Favier, N Meunier, JM O'Connor, G Maiani, C Coudray and AM Roussel, unpublished results) and in in vitro LDL oxidizability reported in the present study. It is also possible that the in vitro oxidation induced by $\mathrm{Cu}$ could be particularly drastic and that LDL oxidation induced by other more physiological or mild inducers, such as 
Zinc supplementation and LDL oxidation

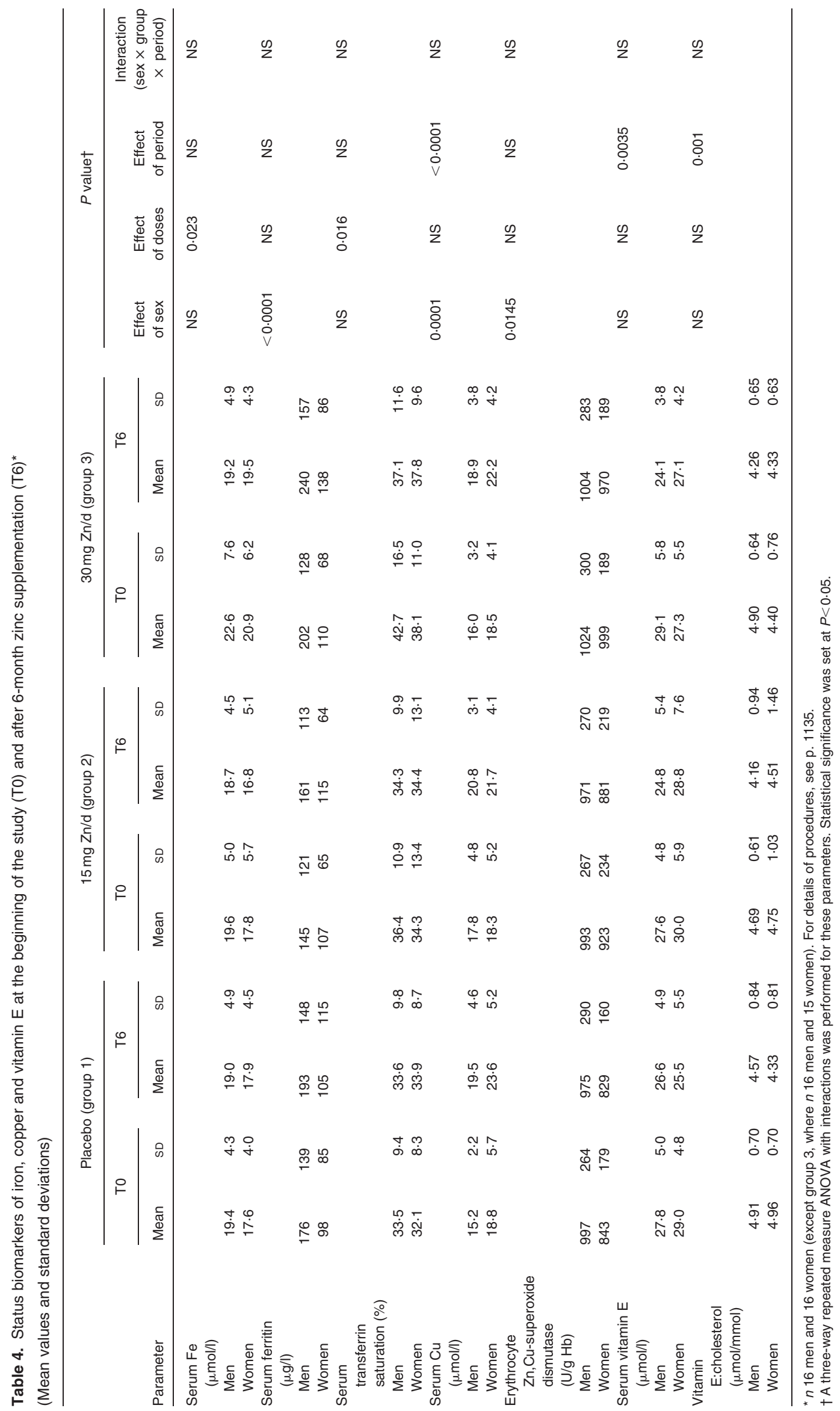


haem-iron (Grinshtein et al. 2003; Klouche et al. 2004) or monocytes-macrophages (Wilkins \& Leake, 1994; Chisolm et al. 1999), may be more appropriate. Consequently, new approaches need to be developed to determine LDL oxidizability with mild inducers, and preferably in their biological medium without isolation and where LDL oxidizability can be measured without elimination of the many protective molecules that LDL may contain when they are in their biological medium.

The susceptibility of LDL to oxidation is influenced also by inherent LDL composition, which has been shown to determine the degree of resistance to oxidative stress. Indeed, it is well known that $\mathrm{Zn}$ status modulates lipid metabolism (Hiller et al. 1995; Schlegel-Zawadzka et al. 2004) and Zn supplementation may lead to modifications in the lipid composition of LDL, in particular fatty acids. Such modifications may, in turn, modify LDL oxidizability. In the present study, we observed no modification in serum cholesterol, expressed as total or lipoprotein-cholesterol, nor in serum triacylglycerol levels in Zn-supplemented groups; but fatty acid composition was not determined. It has been reported that moderate $\mathrm{Zn}$ supplementation did not modify lipid profiles in a late-middle-aged population (Bonham et al. 2003), which is in agreement with our results. However, other studies have shown significant modifications in lipid profiles under $\mathrm{Zn}$ supplementation (Hooper et al. 1980; Freeland-Graves et al. 1982; Chandra, 1984; Black et al. 1988) that might be explained by the higher doses of supplemental Zn given in these studies. LDL resistance to oxidation also depends on the presence of antioxidants together with substrates for oxidation in the lipoprotein. Plasma vitamin E, which plays an important role in the kinetics of lipoprotein oxidation, remained constant throughout the study, as previously reported (Gatto \& Samman, 1995). This shows that Zn supplementation was not efficient in preserving plasma vitamin $\mathrm{E}$ and may partially explain why $\mathrm{Zn}$ supplementation was not efficient in attenuating in vitro LDL oxidation in the present study.

In conclusion, although $\mathrm{Zn}$ status significantly improved in the present study, our results showed that a 6-month Zn supplementation at moderate doses in healthy French subjects aged 55-70 years had no effect on in vitro $\mathrm{Cu}$-induced $\mathrm{LDL}$ oxidation. This may be owing to adequate $\mathrm{Zn}$ status of the subjects at the beginning of the study and supplemental $\mathrm{Zn}$ that was thus not efficient in further improving antioxidant status of those subjects.

\section{Acknowledgements}

The authors would like to thank L. Morin, N. Mathieu and G. Manhiot from the Human Nutrition Unit of Clermont-Ferrand for their collaboration. We also thank L. Jaffrelo, S. Thien (INRA, Clermont-Ferrand, France) and E. Azzini (INRAN, Rome, Italy) for technical assistance, and Dr J. Arnaud (Grenoble Hospital, France), Dr F. Intorre (INRAN, Rome, Italy) and Prof. K. Cashman (Cork University, Ireland) for their contribution to some of the analyses. The authors also express their appreciation to the subjects for their complete co-operation. The Zenith Study is supported by the European Commission 'Quality of Life and Management of Living
Resources' Fifth Framework Program, contract no. QLK1-CT-2001-00 168.

\section{References}

Anderson RA, Roussel AM, Zouari N, Mahjoub S, Matheau JM \& Kerkeni A (2001) Potential antioxidant effects of zinc and chromium supplementation in people with type 2 diabetes mellitus. $J$ Am Coll Nutr 20, 212-218.

Andriollo-Sanchez M, Hininger-Favier I, Meunier N, et al. (2005) Zinc intake and status in middle-aged and older European subjects: the ZENITH study. Eur J Clin Nutr 59, S37-S41.

Arnaud J (2001) Zinc. In Apports nutritionnels conseillés pour la population française, pp. 155-158 [A Martin, editor]. Paris: TecDoc.

Arnaud J, Bellanger J, Bienvenu F, Chappuis P \& Favier A (1986) Recommended method for assaying serum zinc with flame atomic absorption. Ann Biol Clin (Paris) 44, 77-87.

Azaïs-Braesco V, Bruckert E, Durier P, Lecerf JM, Pascal G, Hercberg S, Bourgeois C \& Leger C (2001) Vitamin E. In Apports nutritionnels conseillés pour la population française, pp. 236-243 [A Martin, editor]. Paris: TecDoc.

Balaban RS, Nemoto S \& Finkel T (2005) Mitochondria, oxidants, and aging. Cell 120, 483-495.

Beattie JH \& Kwun IS (2004) Is zinc deficiency a risk factor for atherosclerosis? Br J Nutr 91, 177-181.

Black MR, Medeiros DM, Brunett E \& Welke R (1988) Zinc supplements and serum lipids in young adult white males. Am J Clin Nutr 47, 970-975.

Blostein-Fujii A, DiSilvestro RA, Frid D, Katz C \& Malarkey W (1997) Short-term zinc supplementation in women with non-insulin-dependent diabetes mellitus: effects on plasma $5^{\prime}$-nucleotidase activities, insulin-like growth factor I concentrations, and lipoprotein oxidation rates in vitro. Am J Clin Nutr 66, 639-642.

Bonham M, O'Connor JM, Alexander HD, Coulter J, Walsh PM, McAnena LB, Downes CS, Hannigan BM \& Strain JJ (2003) Zinc supplementation has no effect on circulating levels of peripheral blood leucocytes and lymphocyte subsets in healthy adult men. Br J Nutr 89, 695-703.

Bray TM \& Bettger WJ (1990) The physiological role of zinc as an antioxidant. Free Radic Biol Med 8, 281-291.

Briefel RR, Bialostosky K, Kennedy-Stephenson J, McDowell MA, Ervin RB \& Wright JD (2000) Zinc intake of the U.S. population: findings from the third National Health and Nutrition Examination Survey, 1988-1994. J Nutr 130, 1367S-1373S.

Chandra RK (1984) Excessive intake of zinc impairs immune responses. JAMA 252, 1443-1446.

Chisolm GM 3rd, Hazen SL, Fox PL \& Cathcart MK (1999) The oxidation of lipoproteins by monocytes-macrophages. Biochemical and biological mechanisms. J Biol Chem 274, 25959-25962.

Coudray C (2001) Cuivre. In Apports nutritionnels conseillés pour la population française, pp. 158-161 [A Martin, editor]. Paris: TecDoc.

Coudray C \& Hercberg C (2001) Fer. In Apports nutritionnels conseillés pour la population française, pp. 150-155 [A Martin, editor]. Paris: TecDoc.

Coudray C, Rachidi S \& Favier A (1993) Effect of zinc on superoxide-dependent hydroxyl radical production in vitro. Biol Trace Elem Res 38, 273-287.

DiSilvestro RA (2000) Zinc in relation to diabetes and oxidative disease. J Nutr 130, 1509S-1511S.

Favier JC, Ireland-Ripert J, Toque C \& Feinberg M (1995) Répertoire général des aliments, 2nd ed. Paris: Lavoisier Tec\&Doc.

Feillet C, Roche B, Tauveron I, Bayle D, Rock E, Borel P, Rayssiguier Y, Thieblot P \& Mazur A (1998) Susceptibility to 
oxidation and physicochemical properties of LDL in insulin-dependent diabetics. Atherosclerosis 136, 405-407.

Freeland-Graves JH, Friedman BJ, Han WH, Shorey RL \& Young R (1982) Effect of zinc supplementation on plasma high-density lipoprotein cholesterol and zinc. Am J Clin Nutr 35, 988-992.

Galan P, Viteri FE, Bertrais S, et al. (2005) Serum concentrations of beta-carotene, vitamins $\mathrm{C}$ and $\mathrm{E}$, zinc and selenium are influenced by sex, age, diet, smoking status, alcohol consumption and corpulence in a general French adult population. Eur J Clin Nutr 59, $1181-1190$.

Gatto LM \& Samman S (1995) The effect of zinc supplementation on plasma lipids and low-density lipoprotein oxidation in males. Free Radic Biol Med 19, 517-521.

Gibson RS (1990) Principles of Nutritional Assessment. New York: Oxford.

Grinshtein N, Bamm VV, Tsemakhovich VA \& Shaklai N (2003) Mechanism of low-density lipoprotein oxidation by hemoglobinderived iron. Biochemistry 42, 6977-6985.

Harman D (1992) Role of free radicals in aging and disease. Ann N Y Acad Sci 673, 126-141.

Hennig B, Toborek M \& McClain CJ (1996) Antiatherogenic properties of zinc: implications in endothelial cell metabolism. Nutrition 12, 711-717.

Hercberg S, Galan P, Preziosi P, Roussel AM, Arnaud J, Richard MJ, Malvy D, Paul-Dauphin A, Briancon S \& Favier A (1998) Background and rationale behind the SU.VI.MAX Study, a prevention trial using nutritional doses of a combination of antioxidant vitamins and minerals to reduce cardiovascular diseases and cancers. Supplementation en VItamins et Mineraux AntioXydants Study. Int J Vitam Nutr Res 68, 3-20.

Hill T, Meunier N, Andriollo-Sanchez M, Ciarapica D, Hininger-Favier I, Polita A, O'Connor JM, Coudray C \& Cashman KD (2005) The relationship between the zinc nutritive status and biochemical markers of bone turnover in older European adults: the ZENITH study. Eur J Clin Nutr 59, S73-S77.

Hiller R, Seigel D, Sperduto RD, et al. (1995) Serum zinc and serum lipid profiles in 778 adults. Ann Epidemiol 5, 490-496.

Hininger IA, Meyer-Wenger A, Moser U, et al. (2001) No significant effects of lutein, lycopene or beta-carotene supplementation on biological markers of oxidative stress and LDL oxidizability in healthy adult subjects. $J$ Am Coll Nutr 20, 232-238.

Hooper PL, Visconti L, Garry PJ \& Johnson GE (1980) Zinc lowers high-density lipoprotein-cholesterol levels. JAMA 244, 1960-1961.

Jones DP, Mody VC Jr, Carlson JL, Lynn MJ \& Sternberg P (2002) Redox analysis of human plasma allows separation of pro-oxidant events of aging from decline in antioxidant defenses. Free Radic Biol Med 33, 1290-1300.
Khalil A, Wagner JR, Lacombe G, Dangoisse V \& Fulop T (1996) Increased susceptibility of low-density lipoprotein (LDL) to oxidation by gamma-radiolysis with age. FEBS Lett 392, 45-48.

Klouche K, Morena M, Canaud B, Descomps B, Beraud JJ \& Cristol JP (2004) Mechanism of in vitro heme-induced LDL oxidation: effects of antioxidants. Eur J Clin Invest 34, 619-625.

Le Moullec N, Deheeger M, Preziosi P, et al. (1996) Validation du manuel-photos utilis dans l'enquête alimentaire SU.VI.MAX. Cah Nutr Diet 31, 158-164.

McClain C, Morris P \& Hennig B (1995) Zinc and endothelial function. Nutrition 11, 117-120.

Maggio D, Barabani M, Pierandrei M, Polidori MC, Catani M, Mecocci P, Senin U, Pacifici R \& Cherubini A (2003) Marked decrease in plasma antioxidants in aged osteoporotic women: results of a cross-sectional study. J Clin Endocrinol Metab 88, $1523-1527$.

Maiani G, Mobarhan S, Ceccanti M, Ranaldi L, Gettner S, Bowen P, Friedman H, De Lorenzo A \& Ferro-Luzzi A (1989) Beta-carotene serum response in young and elderly females. Eur J Clin Nutr 43, 749-761.

Napoli C, Abete P, Corso G, Malorni A, Postiglione A, Ambrosio G, Cacciatore F, Rengo F \& Palumbo G (1997) Increased low-density lipoprotein peroxidation in elderly men. Coron Artery Dis 8, 129-136.

Powell SR (2000) The antioxidant properties of zinc. J Nutr 130, $1447 \mathrm{~S}-1454 \mathrm{~S}$.

Rayssiguier Y, Gueux E, Bussiere L \& Mazur A (1993) Copper deficiency increases the susceptibility of lipoproteins and tissues to peroxidation in rats. $J$ Nutr 123, 1343-1348.

Reaven PD, Napoli C, Merat S \& Witztumc JL (1999) Lipoprotein modification and atherosclerosis in aging. Exp Gerontol 34, 527-537.

Roussel AM, Kerkeni A, Zouari N, Mahjoub S, Matheau JM \& Anderson RA (2003) Antioxidant effects of zinc supplementation in Tunisians with type 2 diabetes mellitus. J Am Coll Nutr 22, 316-321.

Schlegel-Zawadzka M, Przysawski J \& Walkowiak J (2004) Zinc supplementation altered phospholipids' fatty acids pattern in young healthy women. Asia Pac J Clin Nutr 13, S156.

Turley E, McKeown A, Bonham MP, et al. (2000) Copper supplementation in humans does not affect the susceptibility of low density lipoprotein to in vitro induced oxidation (FOODCUE project). Free Radic Biol Med 29, 1129-1134.

Vaquero MP (2002) Magnesium and trace elements in the elderly: intake, status and recommendations. J Nutr Health Aging 6, 147-153.

Wilkins GM \& Leake DS (1994) The effects of free radical scavengers on the oxidation of low-density lipoproteins by macrophages. Biochim Biophys Acta 1215, 250-258. 